\title{
COVID-19 and Trade in Africa: Impacts and Policy Response*
}

\author{
WOUBET KASSA $^{\dagger}$
}

\begin{abstract}
Measures adopted to curtail the spread of COVID-19 have led to a sharp contraction of the global economy and an even larger decline in global trade, with significant implications on the livelihoods of people in Africa. Despite the relatively low number of cases, the region's economy would be hard hit due to its high reliance on trade, heavy dependence on commodities, a fragile food system, and limited fiscal capacity to respond. This reinforces the region's inherent vulnerabilities, posing risks of wiping out the gains made in poverty reduction. Countries that have been registering robust growth face rapid growth declines. The response calls for a regional and global coordination to scale up safety nets, facilitate flow of essential goods and ease the region's debt burden to free some fiscal space. There is a need for active policies to support enterprises so that disruptions are not permanent. This requires coordinated effort between government, workers organizations, global lead firms as well as domestic firms. This may also provide opportunities to introduce reforms that would otherwise be considered sweeping. As they chart their operations, beyond the pandemic, countries should reconsider their industrial policies and firms need to rethink their strategies to address emerging uncertainties.
\end{abstract}

\section{COVID-19 will have a SEVERe economic IMPACt IN Africa: Trade is the Key Channel}

The COVID-19 pandemic is first and foremost a health crisis. However, measures to curtail its spread have led to a sharp contraction of the global economy and an even larger decline in trade, with significant implications on the livelihoods of people in Sub-Saharan Africa (SSA). The number of confirmed cases of COVID-19 has been relatively low in SSA (Figure 1a), compared to other regions. However, nowhere will the pandemic hit harder, or with greater adverse impacts on the economic, social, and political life of people, than in SSA, mainly due to the inherent vulnerabilities. Economic growth in SSA is expected to decline to between -2.1 and -5.1 percent in 2020, the first continent-wide recession in a quarter of a century ${ }^{A}$. The economic impact will be hardest felt through trade, due to the rare mix of global shocks in demand and supply. Trade is also key to the solution, both in the direct measures to control the spread of the virus and in minimizing the economic fallout. This brief focuses on trade impacts and policy responses with respect to the latter.

\footnotetext{
${ }^{*}$ This brief has benefited from very useful comments and suggestions from Zainab Usman and Albert Zeufack from the World Bank Group

${ }^{\dagger}$ Office of the Chief Economist for Africa, World Bank. Email: wkassa1@worldbank.org
} 
Figure 1: Total Confirmed COVID-19 Cases in the World and in Continental Africa

(Source: Our World in Data, Accessed May 20, 2020) (update later)

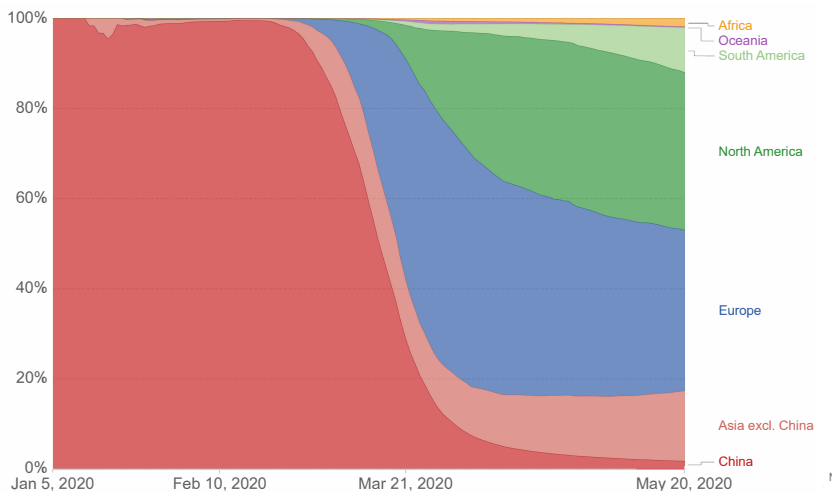

(a) Share of total/global Confirmed COVID-19 Cases

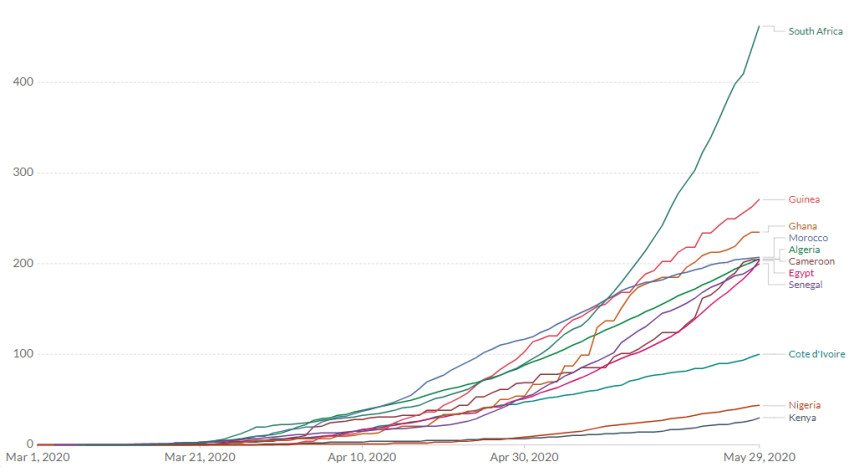

(b) Daily Confirmed COVID-19 Cases per million people

The trade impacts of COVID-19 are amplified since countries most affected by the pandemic represent a significant share of global production and trade. Countries most affected, mainly the U.S., China, Japan, Germany, the U.K., France and Italy, together account for about $60 \%$ of global GDP, 65 percent of global manufacturing and more than 40 percent of global manufacturing exports, while forming key parts of the global value chains (GVCs). In the first quarter of 2020, China's GDP contracted by $6.8 \%$ from the previous year - the largest decline since the early 1990s. In February, the official Manufacturing Purchasing Managers' Index (PMI) hit a record low of 35.7. The U.S. economy contracted at the fastest rate since 2008 , shrinking at a $4.8 \%$ annualized rate in the first quarter of 2020. The downturn in the Eurozone economy is even more severe; the economy contracted $14.4 \%$ over the same period. The COVID-19 related trade collapse is expected to exceed the trade slump of the 2008-2009 financial crisis. Global goods trade is projected to plummet by 13 to $32 \%$. In stark contrast to the 2008-2009 global crisis, where the impact on global trade slowdown was indirect and mainly demand driven, there is now a precipitous slump in production (supply) as well as a sharp collapse in demand. The containment measures adopted in countries most affected by the pandemic result in significant demand shocks, affecting exports and economic growth in SSA.

Though Africa accounts for a very small share of global trade $(\sim 3 \%)$, the share of trade in the national income of most economies in the region is relatively large, compared to other regions. In 2017 the share of trade in GDP was 31\% in North America, 40\% in South Asia, 56\% in SSA and $57 \%$ in EAP. Africa's share of exports to the rest of the world ranged between $80-90 \%{ }^{\mathrm{B}}$ during 2000-2017, higher than any other region except Oceania. Countries most afflicted by the pandemic are also the largest trading partners of the region (Figure 2b). Hence, despite a relatively low share of confirmed cases of COVID-19 thus far, the largest shocks to the region are going to be external. In addition, the lion's share of foreign direct investment (FDI) to SSA comes from these regions, creating a confluence of triple shocks: falling demand for African exports; global supply shocks further curtailing production in export-oriented sectors; and a slump in FDI inflows. The impact of disruptions in GVCs driven by the global demand slump would be predominant in countries with strong forward linkages - mainly exporting raw materials used in the production for export in other countries. This accounts for the largest share of the region's trade and GVC integration (Figure 2a). 
Figure 2: Export Share (\%), By Product Group and Key Partners

(a) Export Share (\%), Major Product Groups (1990-2018)

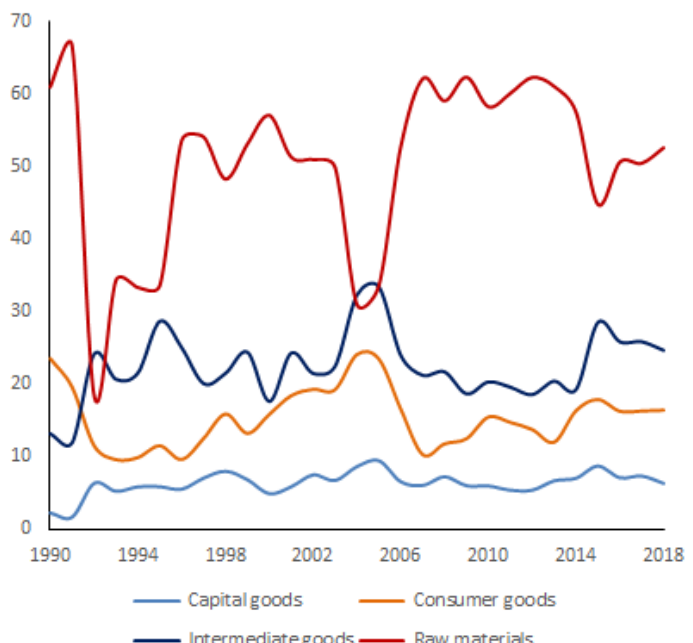

(b) Export Share (\%), Major Trading Partners (1990-2018)

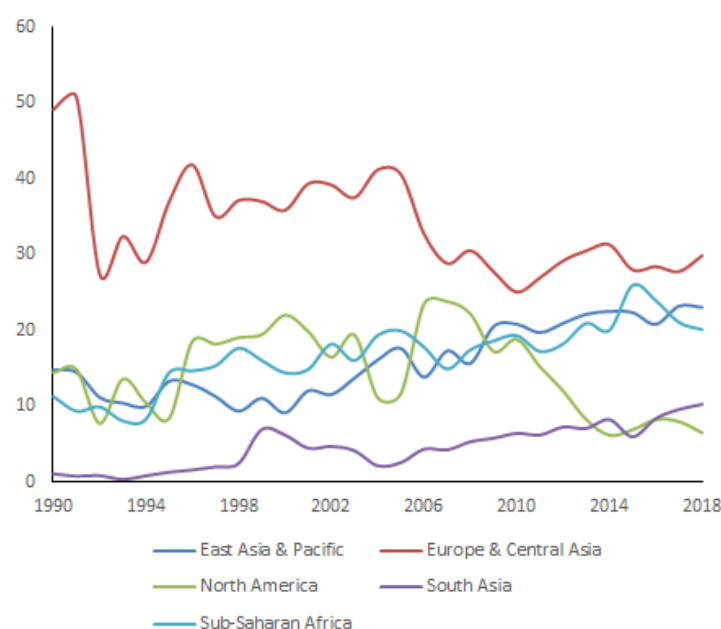

Given the region's high dependence on commodities, the collapse in commodity prices is expected to have very severe impacts, further reinforcing the existing economic vulnerabilities due to lack of diversification. As the pandemic spread, almost all commodity prices saw sharp declines during January-April 2020 (Figure 3a) ${ }^{C}$. In 2019, 89.4\%, or about 9 out of 10 SSA countries were considered commodity dependent(Figure $2 b$, compared to 66 percent in MENA, 50 percent in LAC and 50 percent in East Asia and the Pacific. Hence in countries such as Angola, Nigeria, Republic of the Congo, Chad, Gabon, and Guinea Bissau, the precipitous fall in commodity prices is exacerbating the economic fallout and reinforcing existing social and political vulnerabilities. Two countries most affected by this - Angola and Nigeria - derive $67 \%$ of their revenue and $90 \%$ of their export earnings from oil. At a time when there is additional need to further increase public expenditure to respond to the pandemic directly or limit the subsequent economic pains through social welfare programs, the commodity price shock may instead reduce their capacity to even meet prior commitments. This may contribute to increases in poverty. It could also expose existing political and social vulnerabilities, leading to conflict and instability in the region. 
Figure 3: Commodity Price Indices and Commodity Dependence in Africa

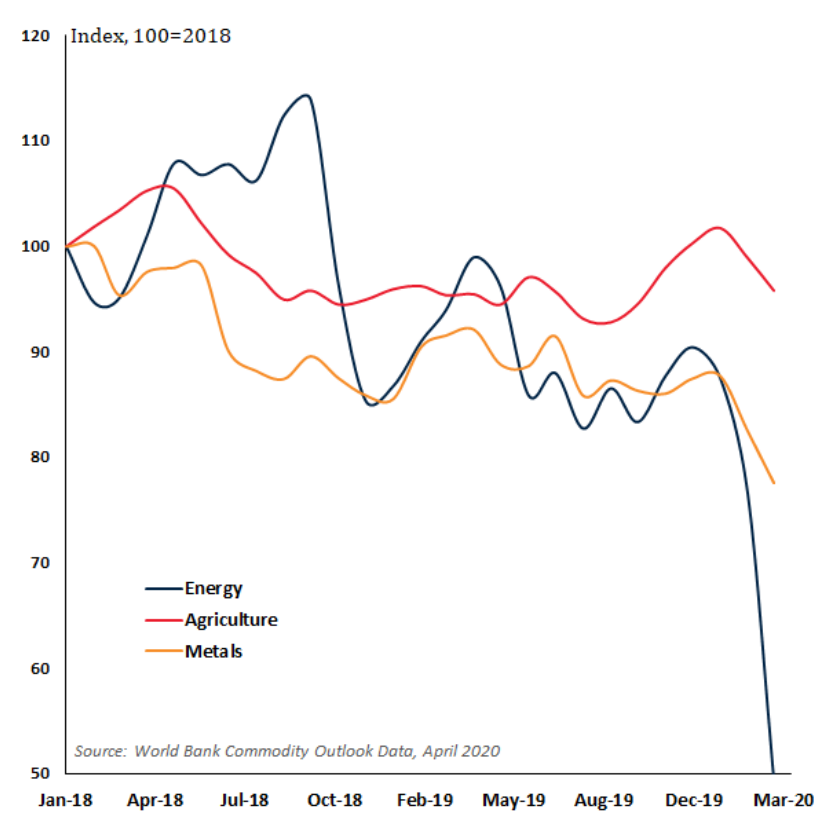

(a) Monthly Commodity Price Indices

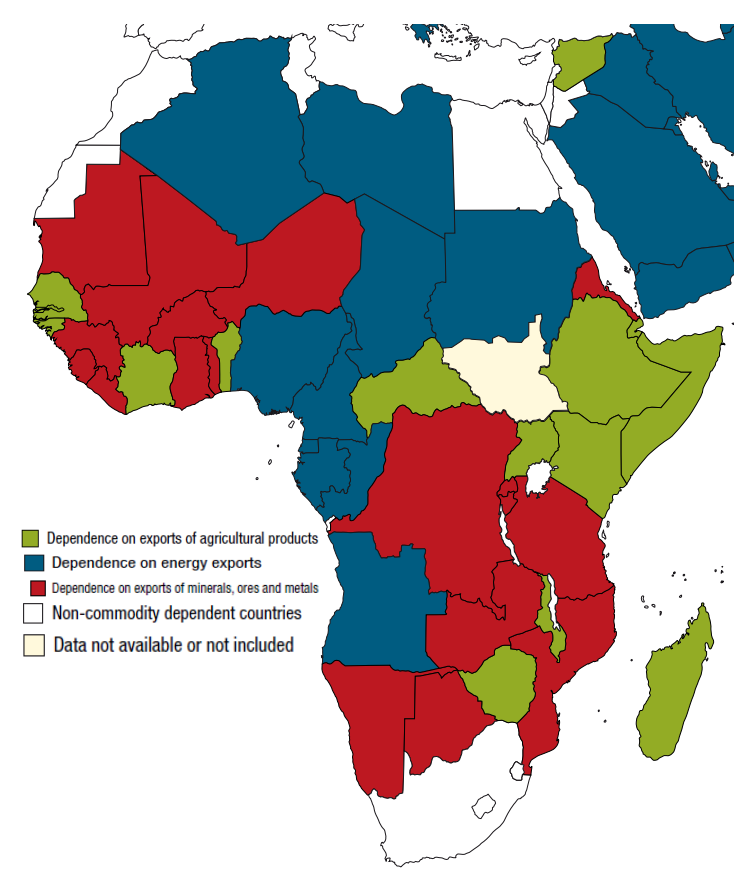

(b) Commodity Dependence in Africa

The supply shocks introduce direct supply disruptions in African countries that are increasingly becoming more integrated into GVCs. Non-resource rich SSA countries that have been sources of robust growth in the region over the last decade will be the most affected. The largest declines in trade are likely to be in sectors with highly integrated global value chains (GVCs). The manufacturing sector will be hard-hit due to the relatively strong GVC linkages. Subsequently, exports are expected to fall due to shortage of intermediate inputs. SSA economies which have been transitioning or are well integrated into manufacturing GVC including South Africa, Kenya, Ethiopia, Lesotho and Eswatini, will be affected the most. These disruptions in production translate into closures of businesses, especially those that export, raising unemployment and poverty. This is worsened by disruptions in international transport networks, which raise the cost of trading. The impacts could be even more severe in countries where commercial services trade such as international passenger and cargo transport and international tourism represent a large share of national income. Since service trade is often complementary to goods trade, the collapse in goods trade will also be followed by a collapse in services trade.

The external trade shocks are compounded by disruptions that are internal to the region, as African countries impose restrictions on the movement of people and goods to limit the spread of the virus. These restrictions have slowed down regional trade with significant economic implications. The share of intraregional exports in total trade is the lowest in Africa; while a large share of the regional trade is informal. Intraregional trade is dominated by manufacturing exports, accounting for 45 percent of intra-African exports. Hence, lock-down measures to control the virus will have negative impacts on the manufacturing sector in the region. In addition, a large share of regional trade, often missing from official trade statistics, is informal. The nature of informal trade is that it is dominated by small-scale producers and traders, engaged in agriculture and other primary sectors. As of May 26, 2020, 43 African countries had closed their borders. There are frequent reports of long lines of trucks at borders across the region, following disputes of incoherent processes in the response to the pandemic. Substantial disruption to regional trade and 
agricultural supply chains could lead to increased risks of food insecurity and poverty in a region that is already home to the largest number of the global poor and the food insecure.

\section{Trade Policy Responses to Mitigate the Shocks}

The first policy action is to do no harm. Blanket Protectionist policies would do more harm than good. Open trade in both goods and services plays a key role in overcoming the pandemic and limiting its health and economic impact, especially on the poor. Restrictive trade policies adopted by African and other ${ }^{D}$ countries during the crisis affect the cost and availability of COVID-19-related medical supplies as well as necessities, mainly food. African countries depend heavily on imports of medical supplies, with 94 percent $^{\mathrm{E}}$ of pharmaceuticals in the region imported from outside the region. The experience from the 2006-2008 commodity price hike demonstrates that export restrictions on food are contagious and lead to increasing uncertainties and further price hikes, worsening the problem. Even when they work, export bans on food may lower domestic prices, which reduces the incentive to grow food crops in the next season. On the other hand, reducing tariff and non-tariff barriers can help facilitate the flow of such goods, supporting response efforts. While many African countries have adopted measures to reduce trade barriers, the region lags behind the rest of the world in reducing both tariff and non-tariff measures on imports of COVID-19 related goods and essential supplies.

Countries should strengthen trade facilitation to streamline and simplify regulatory and border procedures across the region, by improving the efficiency of services and by increasing access to trade finance. Through collaborative frameworks, countries should aim to reduce the administrative time and transaction costs of trading across borders, by improving customs procedures, reducing customs clearance times, establishing one-stop shops, and streamlining regulations across borders. Governments need to invest in transitioning customs and other trading transactions to electronic and digital platforms. In Kenya, for example, the ministry of agriculture won't be renewing tea and coffee auctions if traders fail to permanently migrate trading to an online platform in two months. Similar efforts could help transition customs and trading platforms into more efficient systems, hence reducing costs of trading in the long term.

Deeper regional coordination in trade and COVID-19 response is necessary, both to limit the spread of the pandemic in the region, and to minimize the immediate and long-term economic fallout. Africa can leverage the recent momentum in the Africa Continental Free Trade Area (AfCFTA) and the Regional Economic Communities (RECs) to coordinate response efforts and address long-term challenges including commodity dependence and vulnerability of agricultural supply chains. Regional integration, particularly intra-Africa trade, has been found to strengthen the capacity of economies to absorb global shocks and build resilience to shocks in advanced economies $^{\mathrm{F}}$. In addition, regional integration could provide the pathway to transition out of commodity dependence, since it promotes exchange in a more diverse set of goods (versus trade in concentrated primary goods). In 2017, the share of manufacturing goods in total intra-Africa trade averaged 52 percent compared to 22 percent in agriculture and even lower in fuels trade. Although Africa has comparative advantages in agricultural goods exports, the composition of its exports tends to be skewed towards manufactured goods in trade within the region. This suggests that agriculture and intra-Africa trade in agriculture are underdeveloped, offering unexploited opportunity for this sector in intra-Africa trade. With increasing regionalization and the rise of robust regional blocs reigning over global trade, African states operating separately would find it challenging to grow faster and reduce poverty on a large scale. The pandemic provides additional impetus to intensify and expedite the effective implementation of AfCFTA to deepen regional trade and integration and lessen SSA's dependence on natural resources.

Through the African Union (AU) and other regional and global forums, African countries 
could benefit from coordinating their responses and mobilizing support from international financial institutions. Due to limited fiscal space further tightened by the reduced growth and deteriorating current account, there is a need for a coordinated global effort to rescue the region from the impacts of the shock. African countries should coordinate their efforts in mobilizing the required support from international financial institutions as well as major creditor nations. They should push for a more open global trade that puts pressure against restrictions on exports of key medical supplies and food items. Regional efforts to retool manufacturing to produce COVID-19 related goods may address the immediate challenges and lessen the cost of disruptions in production. To facilitate such retooling of existing manufacturing capabilities, there is a need for temporary exemption of intellectual property rights protections on COVID-19 related medical goods.

African countries should position themselves to seize opportunities that may arise from the desire to diversify global supply chains and expand into new destinations. The combination of trade-policy shocks and the enduring public health concerns from the pandemic have created uncertainty about the future of trade, resulting in a rethinking ${ }^{G}$ of global value chains (GVCs), possibly leading to a shift in sourcing locations. Limited experience from the Great East Japan earthquake suggests that more diversified supply chain networks lead to firms' resilience to natural disasters. The current crisis has revealed the extent of dependence on Factory China and the risks of concentration of GVCs. A more resilient strategy to reduce the risk of potential supply-chain disruption would be for firms to reduce dependence on any one individual supplier. Vietnam and Bangladesh have been, and are expected to continue to be, the main beneficiaries of this shift. With the right policy mix and active industrial policies, African countries could also present a viable alternative to attract some of these investments, based on their comparative advantages. A robust set of active policy reforms to improve the business climate; improve contract enforcement mechanisms; maintain flexibility in promoting and attracting FDIs; and strengthen complementary services such as finance, transport and communications; and trade facilitation could contribute to attracting such investment to the region. According to a 2019 survey $^{\mathrm{H}}$ that tracks U.S. sourcing executives' plans for textile and apparel manufacturing, the major factors that determine sourcing include: (i.) speed to market; (ii.) production and sourcing cost, including labor cost and access to cheaper yarns and fabric produced locally; (iii.) flexibility and agility with respect to quickly adjusting the delivery, volume, and products based on requests; and (iv.) risks of factory, social, and environmental compliance. Policy reforms that address these key challenges could better position SSA countries as attractive destinations for firms seeking to relocate manufacturing in response to the crisis.

States, in coordination with domestic firms, lead firms, and workers' unions should adopt strategies to sustain businesses through the pandemic and ensure that the recovery is smooth. Due to external demand and supply shocks transmitted through trade and domestic lock-downs, SSA is facing unprecedented disruption of business activities. Despite best efforts, many firms could face the risk of collapse, and the resulting loss of millions of jobs without strong social safety nets could be catastrophic. There are also uncertainties with respect to recovery, and whether production would return to pre-crisis levels after the pandemic. The economic impact of the pandemic may not be short-lived, and many firms will need support to restore operations and maintain productivity growth. This includes easy access to financial services, support for temporarily unemployed workers, market recovery, and other more localized interventions to ensure continuity of production operations, post-crisis. The success of policy responses to restructure essential production, effectively manage disruptions, and the subsequent reopening will determine if a country or a firm comes out of this crisis weakened or resilient. It is also important to consider the risks of political capture in adopting firm and industry specific policies, often fast-tracked and without due discourse, to avoid the pitfalls from the lessons of failed industrial policies in the past. 


\section{CONCLUSION}

Trade and globalization are the channels through which pandemics spread. Trade is also the channel through which the economic impacts transmit across economies, both poor and rich. Africa is unique in many ways compared to other regions. Despite the relatively low number of confirmed cases, the region's economy would be hard hit due to its high reliance on trade, heavy dependence on commodities, an already fragile food system, and limited fiscal capacity to respond to the economic fallout from the crisis. This crisis will reinforce the region's inherent vulnerabilities, posing risks of wiping out the gains made in poverty reduction. SSA countries that have been registering robust growth face rapid growth declines due to disruptions in production and falling global demand. The response calls for a regional and global coordination to scale up safety nets, minimize the risks to long term business disruptions; facilitate flow of essential goods and services and ease the burden on the region's debt requirements to free some fiscal space. There is a need for active policies to support enterprises so that disruptions are not permanent, and the shocks do not persist. This requires coordinated effort between governments, workers organizations, and global lead firms as well as domestic firms. This challenge could also provide opportunities to actively introduce reforms, not only to address short-term shocks, but also introduce aggressive reforms that would otherwise be considered sweeping. As they chart their future beyond the pandemic, African countries should reconsider their industrial policies and encourage firms to rethink their strategies to address emerging uncertainties.

\section{REFERENCES}

Baldwin, R. and Tomiura, E. (2020). Thinking ahead about the trade impact of covid-19. Economics in the Time of COVID-19, 59.

Brixiová, Z., Meng, Q., and Ncube, M. (2015). Can intra-regional trade act as a global shock absorber in africa? IZA Discussion Paper, (9205).

Calderon, C., Kambou, G., Zebaze Djiofack, C., Korman, V., Kubota, M., and Cantu Canales, C. (2020). Africa's pulse, no. 21, spring 2020: An analysis of issues shaping africa's economic future.

Coulibaly, S., Kassa, W., and Zeufack, A. (2020). Africa in the new trade environment: Market access in troubled times. forthcoming book (unpublished).

Gruszczynski, L. (2020). The covid-19 pandemic and international trade: Temporary turbulence or paradigm shift? European Journal of Risk Regulation, pages 1-6.

Jobs Creation Commission (2020). Covid-19: Ethiopia potential impact on jobs, incomes and short-term policy options. ILO, Ethiopia.

Lu, S. (2019). 2019 fashion industry benchmarking study. United States Fashion Industry Association.

UNCTAD (2019). Economic development in africa report 2019: Made in africa - rules of origin for enhanced intra-african trade.

UNCTAD (2020). State of commodity dependence 2019. United Nationals Conference on Trade and Development. United Nations, Geneva.

World Bank (2020). World development report 2020: Trading for development in the age of global value chains. World Bank Group: Washington, DC, USA. 


\section{Notes}

ACalderon et al. (2020, pp.44-45)

BUNCTAD (2019, p.19)

${ }^{\mathrm{C}} \mathrm{A}$ country is considered to be export-commodity-dependent when more than 60 per cent of its total merchandise exports are composed of commodities UNCTAD (2020, p. iv.)

DMore than 20 countries have announced a ban on the export of medical gear including personal protective equipment. These include many OECD countries who account for a large share of the export of these goods - South Korea, Taiwan, France, Germany, Russia and India among others. The EU has also restricted export of PPEs, requiring authorizations.

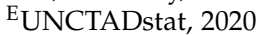

${ }^{\mathrm{F}}$ Brixiová et al. (2015, p. 11)

GBaldwin and Tomiura (2020, pp. 68-69), Gruszczynski (2020, pp. 68-69)

${ }^{\mathrm{H}} \mathrm{Lu}(2019)$ 